\title{
Trypanosoma cruzi Chagas, 1909: Genetic Variability of Isolates from Chronic Chagasic Patients in the Paraná State, Brazil
}

\author{
Rogério Luiz Kopp ${ }^{1}$, Márcia Miyazaki ${ }^{2}$ and Vanete Thomaz-Soccol ${ }^{3 *}$ \\ ${ }^{1}$ Departamento Patologia Médica; Setor de Saúde; Universidade Federal do Paraná; ${ }^{2}$ Hospital de Clínicas; \\ Universidade Federal do Paraná; ${ }^{3}$ Departamento de Patologia Básica; Universidade Federal do Paraná; Centro \\ Politécnico; Jardim das Américas; Curitiba - PR - Brazil
}

\begin{abstract}
The present work had as objective to verify the genetic diversity among strains of Trypanosoma cruzi isolated in chronic chagasic patients in the Paraná state. Fifty patients with compatible clinical symptoms were selected (cardiopathy, megacolon and/or megaesophagus) and that presented positive serological reaction to $\underline{T}$. cruzi. Six strains of the protozoan were isolated in hemoculture and identified by electrophoresis in starch thick gel with aid of

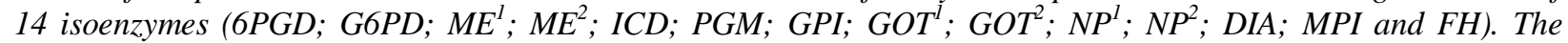
statistical analysis were accomplished by the softwares NTSYs and UPGMA. Eighty-four electromorphs were individualized and four isoenzymes (ICD, GPI, 6PGD, e PGM) showed compatibility for heterozygosis. The phenetic analysis evidenced the hypothesis of constant evolution (genetic distances $=0.0536$ to 0.1429, HardyWeinberg $=1.0000$ to 0.0769 and differentiation for exact tests $=1.0000$ to 0.0658). A great intra-specific genetic diversity in $\underline{T}$. cruzi was verified in the isolates obtained in humans and it indicates that the clonet II is associated to the domestic cycle of transmission.
\end{abstract}

Key words: Trypanosoma cruzi, Multilocus enzyme electrophoresis, Chagas disease, Epidemiology, Phenetic analysis

\section{INTRODUCTION}

Chagas disease or American Trypanosomosis is a public health concern in all Latin America, being its etiological agent the Trypanosoma cruzi Chagas, 1909. This anthropozoonosis reaches nowadays 16 to 18 million people, every year 500.000 new cases are registered and 90 million individuals are exposed to the risk (Carvalho et al., 1997). The disease is characterized by a great variability of symptoms. Even so the evolution determinism to a clinical form or another is not still known, the heterogeneity of parasitic clones could be the basis of this origin.

In natural populations of $T$. cruzi, a great genetic variability has been evidenced mainly with base in isoenzymatic electrophoresis (Miles et al., 1978, Luqueti et al., 1986, Tibayrenc et al., 1986,1988, Carneiro et al., 1990, Romaña et al., 1997, 1999, Brisse, 1998). This parasite presents a typical clonal genetic population structure. Certain genotypes were isolated in a repeated way in distant time and places. Different strains circulate in sylvatic, peridomestic and domestic niches, with different vectors and reservoirs, which

" Author for correspondence 
demonstrate its plasticity. The genetic variability study has been widely evaluated, aiming to correlate with different pathogenic, immunological, biochemical, pharmacological and epidemiological manifestations (Nussenweig et al., 1963, 1966, Miles et al., 1978, Postan et al., 1986, Finly e Dvorak, 1987, Brisse, 1998, ThomazSoccol, et al., 2002, Diosque et al., 2003).

In the Paraná state, the history of Chagas disease is known since the last century and it begins with Florêncio Gomes in 1916 signing by the first time the triatomine Panstrongylus megistus Burmeister, 1835, in Tibagi (Neiva and Pinto, 1923). The first reference about the endemic Chagas disease in Paraná, was in 1919, when four acute cases were identified, exhibiting evident Romaña sign (Souza Araújo, 1954). Already in 1943, the percentile of triatomines infected with the protozoan was studied and it was verified an index of $47 \%$, alerting, in this period, for possible propagation of the disease in rural areas (Simões, 1943). In 1966 Luz and Borba had accomplish a screening of triatomines species in Paraná state. In the eighties, through serological examinations, it was observed that $4 \%$ of the rural population presented the disease in a symptomatic or asymptomatic way (Camargo et al., 1984). The National Health Foundation realizes extensive campaigns to eradicate the intra-domestic Triatoma infestans. During the decade of 80 and in 1992 the last register of this triatomine was realized in Paraná (JL Silva: personal communication, 2000).

In spite that Chagas disease is well studied in the state, little is known about the genetic diversity of the T.cruzi strains that bypass chagasic patients in Paraná. In 2002 Thomaz-Soccol, et al., have studied the genetic diversity of the protozoan in sylvatic reservoirs and in vectors, evidencing an active sylvatic cycle. Gomes et al., 2003, have studied 32 strains of $T$. cruzi isolated from Chagas's disease patients and four isolates were from patients of Paraná state.

In the present work the genetic variability of Trypanosoma cruzi strains is reported, which were isolated from chronic chagasic patients of Paraná state, Brazil.

\section{MATERIAL AND METHODS}

\section{Parasites and reference strain}

For isolation of T. cruzi strains, in humans, blood of 50 patients were selected from Chagas disease
Clinic of Federal University of Paraná Hospital. These patients were coming from different geographical regions of the state and as selection approach only patients' born in state of Paraná were chosen.

The parasite isolation was realized by hemoculture (Chiari et al., 1989, Luz et al., 1994). The amount of collected blood was $20 \mathrm{ml}$, being distributed 0.5 $\mathrm{ml}$ in each tube. The culture media utilized were N.N.N., TOBBIE and EVANS and LIT. The cultivation was weekly transferred during the first four weeks and every fifteen days until the sixth month. The cultures that didn't present parasites were considered negative.

\section{Sample preparation}

The isolated strains were frozen at $-196^{\circ} \mathrm{C}$ until their utilization. For mass culture preparation, strains were maintained in LIT media at $28^{\circ} \mathrm{C}$ in $15 \mathrm{ml}$ tubes, afterwards in 250 and $500 \mathrm{ml}$ Roux bottles. The protozoans were recovered by centrifugation $\left(3500 \mathrm{~g}, 15\right.$ minutes at $\left.4^{\circ} \mathrm{C}\right)$. Later they were washed with physiologic serum $0.85 \%$ and lysed with hypotonic solution containing enzyme preserver (EDTA $2 \mathrm{mM}$, dithithreitol $2 \mathrm{mM}, \varepsilon$-aminocaproic acid $2 \mathrm{mM}$ ). The soluble fraction was stored in liquid nitrogen until use. A strain was used as reference, denominated Y(Miles et al., 1978) and kindly donated by the Institute of Molecular Biology of Paraná (IBMP).

\section{Isoenzyme analysis}

The isolates identification was realized by electrophoresis in starch thick gel (ThomazSoccol, 1993, Thomaz-Soccol., 2002). Fourteen enzyme loci were utilized for the analysis, 6phosphogluconate dehydrogenase (E.C.1.1.1.44, 6PGD), glucose - 6 phosphate dehydrogenase (E.C.1.1.1.49, G6PD), malic enzyme (E.C.1.1.1.40, $\mathrm{ME}^{1}, \quad \mathrm{ME}^{2}$ ), isocitrate dehydrogenase (E.C.1.1.1.42, ICD), phosphoglucomutase (E.C.5.4.2.2, PGM), glucose phosphate isomerase (E.C.5.3.1.9, GPI), glutamate oxalacetate transaminase (E.C.2.6.1.1, GOT $^{1}$, $\mathrm{GOT}^{2}$ ), purin glucoside phosphorilase (E.C.2.4.2.1, $\mathrm{NP}^{1}$ ) (E.C.2.4.2. ${ }^{*} \mathrm{NP}^{2}$ ), $\quad \mathrm{NADH}$ diaphorase (E.C.1.6.2.2, DIA), manose phosphate isomerase (E.C.5.3.1.8, MPI) and fumarate hydratase (E.C.4.2.1.2, FH). The isolated strains are deposited at the cryobank of the Molecular Parasitology Laboratory (DPB/SCB/UFPR). 


\section{Statistical analysis}

Genetic and genotype diversities were estimated with various indexes, NTSYs version 2.0 (Rohlf, 1985) and TFPGA version 1.3 (Miller, 1997).

\section{RESULTS AND DISCUSSION}

\section{Trypanosoma cruzi strains isolation}

From 50 patients it was possible to isolate six strains of protozoan. The isolation time varied from 60 to 120 days. The patients' origin, age and culture media utilized are listed in Table 1.

\section{Trypanosoma cruzi isolates identification}

*Individualization of electromorphs. Through the 14 studied isoenzymatic systems, 84 electromorphs were isolated being the system considered as locus and the electromorph as Taxonomic Unit (OTUs) (Table 2).

For electromorphs individualization the slowest electrophoretic migration denominated as 1 and so forth. Among the 14 studied isoenzymes a polymorphism could be observed for ICD, GPI, 6PGD and PGM, demonstrating that a high grade of variability exists between T.cruzi strains. The isoenzymes ICD and GPI presented compatible electromorphs with the presence of hetero-zygote organisms. The two bands of homozygote type correspond to the superior and inferior bands of the heterozygote type.

The isoenzymes DIA and $\mathrm{ME}^{1}$ and $\mathrm{ME}^{2}$ were monomorphic for all the isolates, including the reference strain.

The isoenzyme 6-PGD presented electrophoretic profiles at three different loci and the PGM at two loci. The other isoenzymatic systems were monomorphic for all analyzed strains, demonstrating a synapomorphic character for these Trypanosoma cruzi strains.

\section{* Zymodemes individualization}

After established the isoenzymatic profile (group of 14 studied isoenzymes) for each isolate it was constructed a dendrogram, being obtained the formation of three groups with the same isoenzymatic profile or zymodems (Table 3 ).

\section{*Phenetic analysis}

Jaccard similarity coefficients were used to build the dendrogram using the UPGMA grouping method (Sneath and Sokal, 1973), representing the hierarchical relations from a distance matrix, with a constant rate evolution hypothesis.

Table 1 - Trypanosoma cruzi strains isolated from chronic chagasic patients

\begin{tabular}{|c|c|c|c|c|c|c|}
\hline Code & Origin & Age & Isolation media & Collection & Isolation & International code \\
\hline $\mathrm{HC} 10$ & Araguai & 45 & $\begin{array}{c}\text { TobbieandEvan } \\
\mathrm{s}\end{array}$ & $02 / 02 / 00$ & $12 / 04 / 00$ & MHOM/BR/00/HC10 \\
\hline $\mathrm{HC} 03$ & Salto do Itararé & 43 & LIT & $29 / 05 / 00$ & $07 / 08 / 00$ & MHOM/BR/00/HC3 \\
\hline HC27 & Salto do Itararé & 49 & $\begin{array}{c}\text { TobbieandEvan } \\
\mathrm{s}\end{array}$ & $04 / 05 / 00$ & $11 / 08 / 00$ & MHOM/BR/00/HC27 \\
\hline $\mathrm{HC} 43$ & Tomazina & 56 & LIT & $25 / 08 / 00$ & $26 / 12 / 00$ & MHOM/BR/00/HC43 \\
\hline $\mathrm{HC} 45$ & $\begin{array}{l}\text { Siqueira } \\
\text { Campos }\end{array}$ & 45 & $\begin{array}{c}\text { TobbieandEvan } \\
\text { s }\end{array}$ & $04 / 10 / 00$ & $29 / 12 / 00$ & MHOM/BR/00/HC45 \\
\hline $\mathrm{HC} 47$ & $\begin{array}{l}\text { Siqueira } \\
\text { Campos }\end{array}$ & 60 & $\begin{array}{c}\text { TobbieandEvan } \\
\text { s }\end{array}$ & $13 / 10 / 00$ & 08/01/01 & MHOM/BR/01/HC47 \\
\hline
\end{tabular}

Table 2 -Isoenzymatic profile of Trypanosoma cruzi strains isolated from chronic chagasic patients

\begin{tabular}{|c|c|c|c|c|c|c|c|c|c|c|c|c|c|c|}
\hline \multirow[t]{2}{*}{ Strain } & \multicolumn{14}{|c|}{ Isoenzyme } \\
\hline & G6PD & ICD & GPI & DIA & MPI & NP1 & NP2 & 6PGD & GOT1 & GOT2 & PGM & ME1 & ME2 & FH \\
\hline $\mathrm{HC} 10$ & 1 & 3 & 1 & 1 & 3 & 0 & 2 & $1 / 3$ & 2 & 0 & 3 & 1 & 1 & 1 \\
\hline $\mathrm{HC} 27$ & 1 & 3 & 2 & 1 & 3 & 0 & 2 & $1 / 3$ & 2 & 0 & 3 & 1 & 1 & 1 \\
\hline $\mathrm{HC} 3$ & 1 & $1 / 3$ & $1 / 2$ & 1 & 3 & 0 & 2 & $2 / 3$ & 2 & 0 & 3 & 1 & 1 & 1 \\
\hline $\mathrm{HC} 43$ & 1 & 1 & $1 / 2$ & 1 & 3 & 0 & 2 & 1 & 2 & 0 & $2 / 3$ & 1 & 1 & 1 \\
\hline HC45 & 1 & 1 & $1 / 2$ & 1 & 3 & 0 & 2 & 1 & 2 & 0 & $2 / 3$ & 1 & 1 & 1 \\
\hline HC47 & 1 & 1 & $1 / 2$ & 1 & 3 & 0 & 2 & 1 & 2 & 0 & $1 / 2$ & 1 & 1 & 1 \\
\hline Y & 2 & 2 & 2 & 1 & $1 / 2$ & 1 & 1 & 1 & 1 & 1 & 2 & 1 & 1 & $1 / 2$ \\
\hline
\end{tabular}


Table 3 -Individualized zymodemes of Trypanosoma cruzi strains isolated from chronic chagasic patients

\begin{tabular}{lll}
\hline \multicolumn{1}{c}{ Isolates } & Zymodem & International code \\
\hline HC10, HC27 & DPBPAR1 & MHOM/BR/00/HC10 \\
HC3 & DPBPAR2 & MHOM/BR/00/HC3 \\
HC43, HC45, HC47 & DPBPAR3 & MHOM/BR/00/HC43 \\
Y & Zym. Y & Reference strain \\
\hline
\end{tabular}

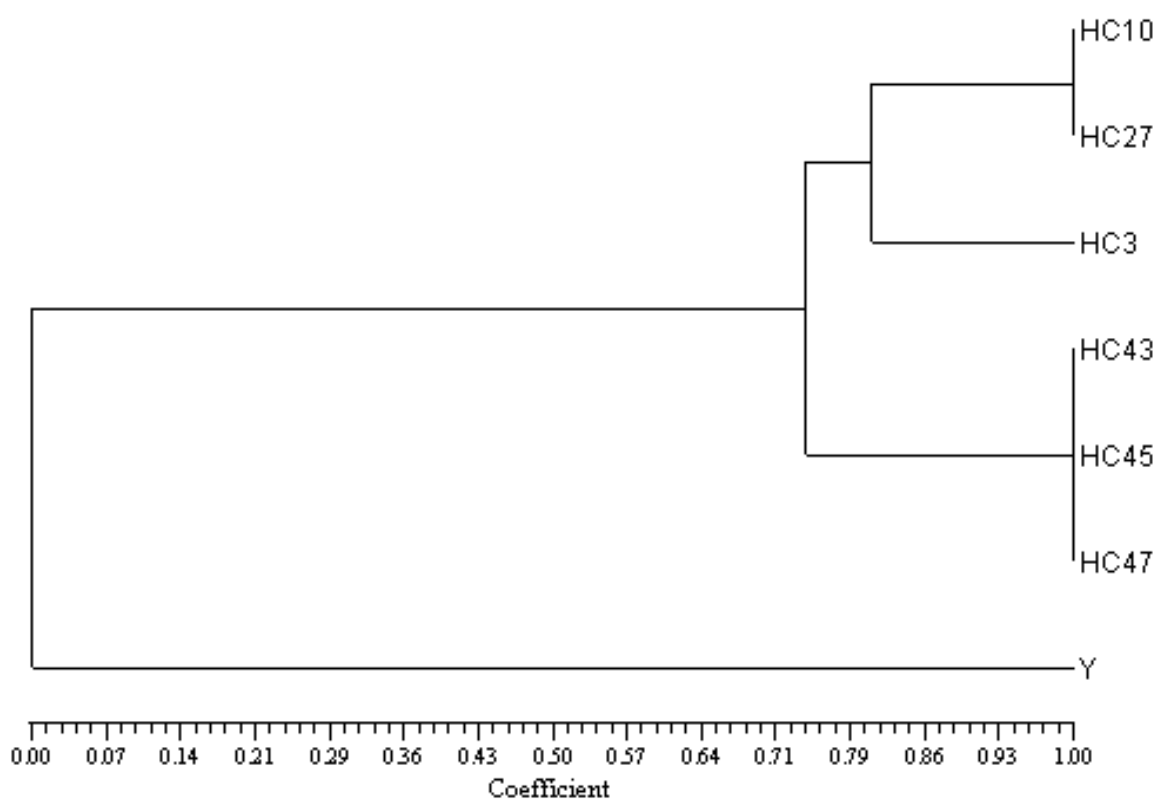

Figure 1 - Dendrogram constructed with Trypanosoma cruzi strains isolated from chronic chagasic patients in the Paraná state and the reference strain Y. Jaccard distances for matrix construction were obtained by isoenzyme electrophoresis.

*Grouping by UPGMA with Nei minimal distances (1972)

Six insert knots with maximum distance of 0.5119 contain respectively six strains of $T$. cruzi. At the level of 0.0536 a grouping of strains $\mathrm{HC} 10, \mathrm{HC} 27$ and $\mathrm{HC} 3$ occurred with distance of 0.1429 for the group of six strains isolated in Paraná state (Fig. 1). These results were appraised through 1000 permutations in order to obtain the replicate proportion corresponding to a smaller index of 0.8600 (Fig. 1). The consistency for grouping formation was obtained with a variation among knots of $7.14 \%$ to $71.43 \%$.

\section{*Group formation}

The constructed dendrogram separates $T$. cruzi strains in two groups, being the first composed by two sub-groups with three sets and the second group composed by only the reference strain (Fig. 1).
This strain presented a similarity index in relation to the first group of 0.8065 . In the third group it happened the grouping of three strains ( $\mathrm{HC} 43$, HC45 and HC47) with similarity index in relation to the first and according to groups of 0.7419 and genetic distance in relation to the first of 0.1859 (Id. $=0.8303$ ) and for the second of 0.1250 (Id. $=0.8825$ ).

In the second group it was isolated the reference strain that presented a genetic distance in relation to the first group of 0.8595 (Id. $=0.4234$ ), second of 0.9676 (Id. $=0.3800)$ and to the third of 0.7536 (Id. $=0.4707)$.

\section{*Isoenzyme variability among the groups}

With the composition of the groupings and separation of two groups and its respective sets, it was possible to verify, among the isoenzymes, the existent genetic variability for $T$. cruzi strains. 
For the whole sampling it was obtained the heterozygotes presence equals to 0.2536 , with impartial value of 0.2732 , and directly counted of 0.1429 . These results expressed a polymorphism percentage among all the locus of $78.57 \%$, being this value obtained with approaches of 95 and 99\%, revealing the high degree of existent polymorphism among the strains of $T$. cruzi.

\section{*Analysis of the isoenzymatic polymorphism}

Having as data base the analysis of the locus, formed by the isoenzymes, the software TFPGA was used, being verified the heterozygote occurrence in 11 locus. The largest index among the variable locus was observed in GPI (0.6224) and the smallest for MPI and FH with index of 0.1327.

For the whole sampling it was obtained the heterozygotes presence equals to 0.2536 , with impartial value of 0.2732 , and directly counted of 0.1429 . These results expressed a polymorphism percentage among all the locus of $78.57 \%$, being this value obtained with approaches of 95 and $99 \%$, revealing the high degree of existent polymorphism among the strains of $T$. cruzi.

\section{*Differentiation among $T$. cruzi strains by exact tests}

With the dememorization (1000) and 2000 permutations, having as base the analysis of the isoenzymes, the existence of differences was determined in the frequency of the electromorphs (Raymound and Rousset, 1995). From the analysis of all the seven strains the values of $p$ varied among 10000 for the isoenzymes MPI and FH until the differences of 0.0658 for $\mathrm{GOT}^{1}$. For the isoenzymes DIA, $\mathrm{ME}^{1}$ and $\mathrm{ME}^{2}$, the analyses were not accomplished because they were monomorphic.

Comparing the isolated strains, in the present work, in relation to the reference strain, the largest probability was observed in relation to the enzymes DIA, 6-PGD, $\mathrm{ME}^{1}$ and $\mathrm{ME}^{2}$ with $\mathrm{p}$ equal to 1.0000 and smallest for $\mathrm{NP}^{1}$ with $\mathrm{p}$ equal to 0.0105 , not having the occurrence of significant standard error for this correlation. Trypanosoma cruzi indeed presents in its natural cycle a high genetic variability and a structure of clonal population (Tibayrenc et al., 1988, Fernandes et al., 1997, Brisse, 1998, Barnabé, 2000, ThomazSoccol, 2002, Diosque, 2003). Clones distributed in two larger phylogenetic lineages compose natural population of $\mathrm{T}$. cruzi. The interpretation of the genetic variability of $T$. cruzi is in debate and still didn't arrive to a larger consent (Zymodemes Z1, Z2, Z3, ZB, ZC and ZD or phylogenetic lineages $T$. cruzi I and $T$. cruzi II).

The present work demonstrated a great genetic diversity of $T$. cruzi circulating strains in humans in the state of Paraná considering just six isolated strains, of patients certainly born in the State, three clonets were evidenced. The intra specific characterization of the protozoan is indispensable for best knowledge of Chagas disease epidemiology in the different focuses and to evaluate the risks of focuses renewal. For this reason it is indispensable to know which are the connection links among domestic, peri-domestic and sylvatic cycle. A subject is imposed: would connection link exist among the domestic and sylvatic cycle of $T$. cruzi in the state of Paraná, or would occur two independent cycles?

Table 04 - Rate of heterozygotes among Trypanosoma cruzi strains

\begin{tabular}{llcl}
\hline \multicolumn{1}{c}{ Enzymes } & Heterozygotes & Impartial & Directly Counted \\
\hline G6PD & 0.2449 & 0.2637 & 0.0000 \\
ICD & 0.5408 & 0.5824 & 0.2857 \\
GPI & 0.6224 & 0.6703 & 0.5714 \\
DAI & 0.0000 & 0.0000 & 0.0000 \\
MPI & 0.1327 & 0.1429 & 0.1429 \\
NP1 & 0.2449 & 0.2637 & 0.0000 \\
NP2 & 0.2449 & 0.2637 & 0.0000 \\
6PGD & 0.4388 & 0.4725 & 0.4266 \\
GOT1 & 0.2449 & 0.2637 & 0.0000 \\
GOT2 & 0.2449 & 0.2637 & 0.0000 \\
PGM & 0.4592 & 0.4945 & 0.4286 \\
ME1 & 0.0000 & 0.0000 & 0.0000 \\
ME2 & 0.0000 & 0.0000 & 0.0000 \\
FH & 0.1327 & 0.1409 & 0.1429 \\
\hline
\end{tabular}




\section{RESUMO}

O presente trabalho teve como objetivo verificar a diversidade genética entre cepas de Trypanosoma cruzi circulantes em pacientes chagásicos crônicos no estado do Paraná. Foram selecionados 50 pacientes com clínica compatível (cardiopatia, megacolo e/ou megaesôfago) e que apresentaram reação sorológica positiva para T. cruzi. Foram isoladas seis cepas do protozoário em hemocultura e identificadas por eletroforese em gel espesso de amido com auxílio de 14 isoenzimas (6PGD; G6PD; $\mathrm{ME}^{1}$; $\mathrm{ME}^{2}$; ICD; PGM; GPI; $\mathrm{GOT}^{1}$; $\mathrm{GOT}^{2}$; $\mathrm{NP}^{1}$; NP${ }^{2}$; DIA; MPI e FH). A análise estatística foi realizada pelos programas NTSYs e TFPGA. Oitenta e quatro eletromorfos foram individualizados sendo que quatro isoenzimas (ICD, GPI, 6PGD, e PGM) apresentaram compatibilidade para heterozigose. A análise fenética evidenciou a hipótese de uma evolução constante (distâncias genéticas $=0,0536$ a 0,1429 , Hardy-Weinberg $=1,0000$ a 0,0769 e diferenciação por exatos testes $=1,0000$ a 0,0658 ). Uma grande diversidade genética intra-específica em Trypanosoma cruzi foi verificada nos isolados obtidos em humanos. È indispensável conhecer se há ou não inter-relação entre o ciclo doméstico e ciclo silvestre deste protozoários.

\section{REFERENCES}

Brisse, S. (1998), Phylogénie moléculaire des clones naturels de Trypanosoma cruzi, agente de la maladie de Chagas: évolution clonale, recombinaison génétique, et relations phylogénétiques avec d'autres espèces du sous-genre Schyzotripanum. Thèse de Doctorat, Université Montpellier II, Montpellier, France.

Barnabé, C.; Brisse, S. and Tibayrenc, M. (2000), Population structure and genetic epidemiology of Trypanosoma cruzi, the agent of Chagas' disease: a multilocus enzyme electrophoresis approach. Parasitology, 120, 513-526.

Camargo, M. E.; Silva, G. R.; Castilho, E. A. and Silveira, A. C. (1984), Inquérito sorológico da prevalência da infecção chagásica no Brasil, 1975 1980. Revista do Instituto de Medicina Tropical de São Paulo, 26, 192-204.

Carneiro, M.; Chiari, E.; Gonçalves, A. M.; SilvaPereira, A. A.; Morel, C. M. and Romanha, A. J. (1990), Changes in the isoenzyme and kinetoplast DNA patterns of Trypanosoma cruzi strains induced by maintenance in mice. Acta Tropica, 47, 35-45.
Carvalho, M. F. C.; Franco, M. F. and Soares, V. A. (1997), Amastigotes forms of Trypanosoma cruzi detected in a renal allograft. Revista do Instituto de Medicina Tropical de São Paulo, 39, 223-226.

Chiari, E.; Dias, J. C. P.; Lana, M. and Chiari, C. A. (1989), Hemocultures for parasitological diagnosis of human chronic Chagas' disease. Revista da Sociedade Brasileira de Medicina Tropical, 22 : (1), 19-23.

Diosque, P.; Barnabé, C.; Padilla, A.; Marco, J.; Cardozo, R.; Cimino, R.; Nasser, J.; Tibayrenc, M. and Basombrio, M. (2003), Multilocus enzyme electrophoresis analysis of Trypanosoma cruzi isolates from a geographically restricted endemic area for Chagas' disease in Argentina. International Journal for Parasitology, 33, 997-1003.

Fernandes, C. D.; Murta, S. M. F.; Ceravolo, I. P.; Krug, L. P.; Vidigal, P. G.; Steindel, M.; Nardi, N. and Romanha, A. J. (1997), Characterization of Trypanosoma cruzi strains isolated from chronic chagasic patients, Triatomines and Opossums naturally infected from the State of Rio Grande do Sul, Brazil. Memórias do Instituto Oswaldo Cruz, 92 : (3), 343-351.

Finley, R. W. and Dvorak, J. A. (1987), Trypanosoma cruzi: Analysis of the population dynamics of heterogeneous mixtures. Journal of Protozoology, 34, 409-415.

Gomes, M. L.; Toledo, M. J. D. and Nakamura, C. V. (2003), Trypanosoma cruzi:Genetic group with peculiar biochemical and behavior, Memorias do Instituto Oswaldo Cruz, 98 : (5), 649-654.

Haldane, J. B. S. (1954), An exact test for randomness of mating. Journal of Genetics, 52, 631-635.

Luquetti, A. D.; Miles, M. A.; Rassi, A.; Rezende, J. M.; Souza, A. A.; Povoa, M. M. and Rodrigues, I. (1986), Trypanosoma cruzi: zymodems associated with acute and chronic Chaga's disease in Central Brazil. Transactions of the Royal Society of the Tropical Medicine and Hygiene, 80, 462-470.

Luz, E. and Borba, A. M. (1966), Triatomíneos encontrados no Paraná-Aspectos biológicos, Annais da Faculdade de Medicina da Universidade Federal do Paraná, 9/10 : (1/2), 165-172.

Luz, Z. M. P.; Coutinho, M. G.; Cançado, J. R. and Krettli, A. U. (1994), Hemocultura: técnica sensível na detecção do Trypanosoma cruzi em pacientes chagásicos na fase crônica da doença de Chagas. Revista da Sociedade Brasileira de Medicina Tropical, 27 : (3), 143-148.

Miles, M. A.; Souza, A. A.; Povoa, M. M.; Shaw, J. J.; Lainson, R. and Toye, P. J. (1978), Isozymic heterogeneity of Trypanosoma cruzi in the first authocthonous patients with Chagas disease in Amazoniam Brazil. Nature, 272, 819-821. 
Miller, P. M. (1997), Tools for population genetic analyses (TFPGA) 1.3. A Windows program for the analysis of allozyme and molecular population genetic data. Computer software distributed by author.

Neiva, A. and Pinto, C. (1923), Representantes dos gêneros Triatoma Lap. e Rhodnius Stal encontrados no Brasil central e sul. Brasil Médico, 37 : (7), 84-86.

Nussenweig, V. and Goble, F. C. (1966), Further studies on the antigenic constitution of strains of Trypanosoma (Schizotrypanum) cruzi. Experimental Parasitology, 18, 224-230.

Nussenweig, V.; Kloetzel, J. and Deane, L. M. (1963), Acquired immunity in mice infected with strains of immunological types A and B of Trypanosoma cruzi. Experimental Parasitology 14,233-239.

Postan, M.; Mcdaniel, J. P. and Dvorak, J. A. (1986), Trypanosoma cruzi: constancy of clone pathogenicity for inbred mice during long-term in vitro maintenance. Transactions of the Royal Society of the Tropical Medicine and Hygiene, 80, 659-662.

Raymound, M. L. and Rousset F. (1995), An exact test for population differentiation. Evolution, 49, 1280-1283.

Rohlf, F. J. (1985), Numerical Taxonomy System of Multivariate Statistical Programs. User's Guides. New York; State University.

Romanha, A. J. (1999), Heterogeneidade Enzimática em Trypanosoma cruzi. In: Murta SMF, Romanha AJ. Characterization of Trypanosoma cruzi. Memórias do Instituto Oswaldo Cruz, 94, 177-180.

Romanha, A. J. (1997), Heterogenidade enzimática em Trypanosoma cruzi. In: Fernandes, C. D.; Murta, S. M. F.; Ceravolo, I. P.; Krug, L. P.; Vidigal, P. G.; Steindel, M.; Nardi, N. and Romanha, A. J. (Eds.). Characterization of Trypanosoma cruzi strains isolated from chronic chagasic patients, triatomines and Opossums naturally infected from the State of Rio Grande do Sul, Brazil. Memórias do Instituto Oswaldo Cruz, 92 : (3), 343-351.

Simões, A. J. P. (1943), Doença de Chagas no Estado do Paraná, Brasil. Esboço epidemiológico. Memórias do Instituto Oswaldo Cruz, 39 : (3), 279-291.

Sneath, P. H. A. and Sokal, R. R. (1973), Numerical taxonomy: the principle and practice of numerical certification. São Francisco : Freeman.

Souza-Araujo, H. C. (1954), A doença de Chagas no Paraná. Memórias do Instituto Oswaldo Cruz, 52 : (2), 477-485.

Tibayrenc, L. and Ayala, F. J. (1988), Isozyme variability in Trypanosoma cruzi, the agent of Chagas disease: genetical, Taxonomical, and Epidemiological significance. Evolution, 42 : (2), 277-292.

Tibayrenc, M.; Ward, P.; Moya, A. and Ayala, F. J. (1986), Natural populations of Trypanosoma cruzi, the agent of Chagas' disease, have a complex multiclonal structure. Proceedings of National Academy of Sciences of USA, 83, 1335-1339.
Thomaz-Soccol, V. (1993), Les Leishmania du Noveau Monde. Analyse enzymatique. Demarche progressive phenetique-cladistique. Tese de Doutorado, Université Montpellier I. Faculté de Medicine, Montpellier, France.

Thomaz-Soccol, V.; Barnabé, C.; Castro, E.; Luz, E. and Tibayrenc, M. (2002), Trypanosoma cruzi: isoenzyme analysis suggests the presence of an active Chagas sylvatic cycle of recent origin in Paraná State, Brazil. Experimental Parasitology, 100, 81-86.

Received: September 21, 2004; Revised: December 17, 2004; Accepted: March 03, 2005. 